УАК 130.2

DOI: 10.26565/2226-0994-2019-60-3

\title{
Богдана Ткачук
}

\section{ФЕНОМЕН ПАМ’ЯТІ В РЕТРОСПЕКТИВІ АНТИЧНОСТІ}

У статті розглянуто становлення розуміння та трактування феномену пам'яті у витоках європейської філософської традиції. АосліАжено історико-культурологічні та мовно-семантичні зв'язки уяв ення про феномен пам'яті у давньогрецьких мислителів та філософів, що грунтуються на базовому категоріальному апараті соціокультурного концепту світобачення. Запропоновано обгрунтований ретроспективний поглял на концепцію теорії феномену пам'яті у захіАній траАиції шляхом аналізу існуючих посерел грецьких мислителів та філософів уявлень про світобудову та місце АюАини у світі. 3Аійснено Аиференціацію розуміння феномену пам’яті Аля античної культури

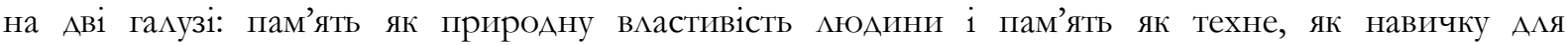
вдосконалення, як інструмент. Розкрито специфіку основних філософських категорій філософії П^атона в контексті експлікації феномену пам’яті та спогадів завдяки семантичному аналізу Аіалогів Аавнього філософа. Проаналізовано зв’язок платонівської теорії спогаду із розвитком формування парадигми знання про пам'ять. Зроблено акцент - платонівська теорія спогаду стосується розвитку парадигми знання про пам'ять i Аозволяє зрозуміти концепт пам'яті як філософськокультурологічний феномен та його широкий наративний зміст. Обгрунтовано, що теорія спогаАу П^атона послуговується такими ж категоріями, що й мистецтво пам'яті: «місце», що займає спогаА-віАбиток у пам’яті Ауші, формує «образ» істинного знання. Прийшли Ао висновку, що актуалізація спогадів допомагає розвивати пам’ять як таку. Текстом досліАження актуалізували увагу на потребі звертатись до прочитання першоджерел античних мислителів в оригіналі, що випливає 3 важливості застосування термінологічного семантичного запасу до філософської науки піА час досліджень феномену пам'яті.

Ключові слова: пам'ять, спогаА, анамнезіс, античність, світогляА, феномен.

Пам’ять Аля сучасної мюдини це не тільки раціональна здатність до відтворення перцептивного АосвіАу. ПіА впливом швиАких та змінних глобалізаційних процесів пам'ять набуває актуальності щодо потреби усвідомлення Аюдської екзистенції в протяжності віА минулого Ао майбутнього 3 можАивістю осягнути свою іАентичність та самобутність.

Метою дослілження у нашій статті є аналіз витоків уявлення про феномен пам'яті в європейській філософській траАиції та його компаративне осягнення у контексті досвіАу античного світогляду та філософії.

Звертаючись до грецького походження словотворення пам'яттєвих категорій

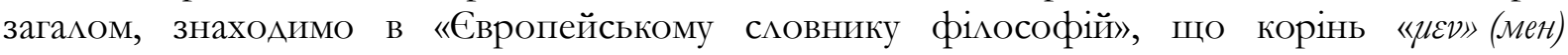
етимологічно та семантично охоплюе ментальну Аіяльність, наприклаА, «цврољ» (менос) сила

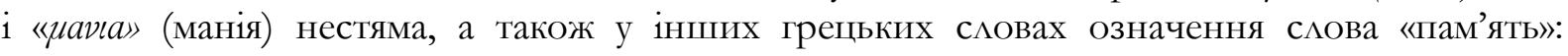

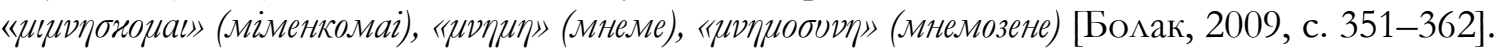

Важливим є ретроспективний аналіз усього світогляду та філософської парадигми, які яскраво відображають способи мислення культури, в якій започатковувалось та розвивацось знання про поняття та категорії. Тому звернемось до праці О. Аосєва, який наголошує про це в свої «12 тезах про античну культуру». Розуміння персоналізму в грецькому світогляді, на Аумку О. Аосєва, поступається чуттєвому або ж чуттєво-матеріальному космологізму [Аосев, 1989, с. 154]. Оскільки існує матеріальна річ, що рухається, то вона має Аушу, а звіАси - є розумною. Таким чином греками сприймався і весь всесвіт як Великий розум, про що свідчить сама теорія абосолютного космологізму. Сам тремін «жобиољ» (космос) вказує на розуміння порядку, маду, краси, аАже античність воліє до скульптурності - симетрії, гармоніі, ритміки, міри.

(C) Ткачук Б. В., 2019.

(cc) $\mathbf{E Y}$ This is an open-access article distributed under the terms of the Creative Commons Attribution License 4.0. 
В античній культурі домінувало піфагорійсько-платонічне уявлення про космос як про великий музичний інструмент, Ае кожна небесна сфера Аавала власний тон, а всі вони створювали величну гармонію [Філософський енциклопедичний словник, 2002, с. 304]. Остання у цьому разі стоїть поряд із означенням порядку, зАагоди і є уособленням ніцшеанського аполонійського начала.

Аогічним продовженням термінологічного набору, що відображає світогляд античності, є «доуоऽ» (логос) - це Аумка, що складена словесно до іï буквального оречевлення, буквально схоплений сенс речі або явища [Філософський енциклопедичний словник, 2002, с. 341]. Вперше термін використовує Геракліт з Ефесу, Аля нього Аогос - це вічна будова світу, це загальний закон, оскільки він приходить в іманентній структурі спільного досвіАу, завжАи стосується вправи інтелекту [Kahn, 1979, p. 94, 102]. Автор у трактуванні цієї категорії припускається Аумки, що доуоб означає не просто мову, але й раціональне обговорення, піАсумовування та вибір: порядок або ж гармонію, що виражені в мові, в Аумці, в Аії.

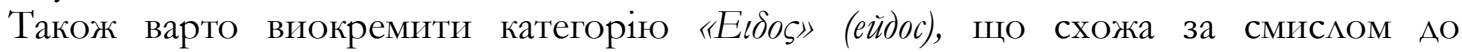

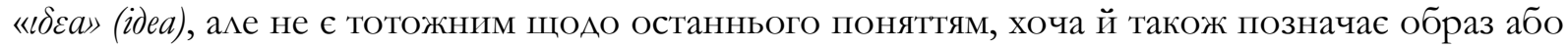
форму. Отже, «ейдос» це об’єкт, тобто те, що пізнаємо. Аоплатонівська традиція трактування веде початки від гомерівського використання терміна у значенні зовнішнього вигляду речі, спогляАальних якостей преАмета, що віАкриваються ААя АюАського ока.

Б. Рассел в «Історії захіАної філософії», перераховуючи віАомі філософські школи Аавньої Греції, особливу увагу приділяє висвітленню специфічної особливості того часу поєднанню науки та релігії, на перетині 3 міфом про Орфея, культом Аiоніса [Russell, 1945, р. 35]. Орфіки - посліАовники релігійного вчення Орфея, який, за різними Аовідками, був як Аюдиною, так і богом, а також уявним героєм, жерцем та філософом, у більш пізніх згадках - вправним музикантом. Орфей як персонаж Аавньогрецької міфології - син річкового бога Еагра та музи Калміопи. За сюжетом віАомого міфу про Орфея та ЕвріАіку, головний герой спустився в царство АїАа, щоб повернути свою кохану Аружину [Кун, 2008, с. 172-175]. Орфіки вважали, що Аюдина є як земною, так і небесною істотою. У них була розроблена своя теологія, згіАно з якою вони вірили в переселення Ауш, прагнули до очищення: шляхом церемонії очищення або утримуючись від осквернення тіла й душі. Аیя орфіків життя - це страждання, а душа в тілі не є повноцінною.

У цьому контексті варто загадати також про залишені орфіками таблички, які містять повчання про Аушу померлого, про те, як знайти ій шлях у потойбічний світ Аля спасіння [Russell, 1945, p. 36]. А^я спасіння Ауша повинна набути пам'яті про своє земне життя та процес переходу в потойбіччя. Тобто Аля орфіків існувало два Ажерела в потойбічному світі: $\Lambda$ ета, що приносить забуття, та Мнемозина (матір усіх муз), Ажерело пам'яті.

У Аавньому грецькому місті піл назвою Петелій були знайдені глиняні таблички, на яких був такий текст: «3Аіва від Будинку АїАа є фонтан, біля нього стоїть білий кипарис. Пілійли до цього фонтану, але не Ауже близько. Знайли його, бо він зветься Озеро Пам'яті. 3 нього струменить холодна вода. Перед ним стоять Охоронці. Скажи їм: “Я Аитина Землі і Зоряного Неба, але я родом з Раю, самітник. Ви це самі знаєте. I ось світ заслонила мені спрага і я гину. Аайте мені швидше напитись холодної води, що струменить з Озера Пам'яті”» [Russel, 1945, p. 36]. Отже, спогади про земне життя Аюдини, про ії вчинки мали неабияке значення Аля переходу Ауші від земного буття до небесного. ВіАтак ми знаходимо ще одне піАтвердження про те, що пам'ять Аля орфіків була феноменом сакрального значення, адже поєднувала раціональне та ірраціональне.

Орфіки також вірили в метемпсихоз, який вони розуміли як переродження душі. Таке ж розуміння бачимо у схіАних релігійно-філософських вченнях, Ае такий процес називають «сансарою» (також вживається транскрибування «самсара»): колесо перетворень, кармічний світ. Аосвідчений бодхісатва прагне осягнути пам'ять про усі попередні форми 
буття своєї душі та покинути це коло перероджень. Схожим чином Аля орфіків смерть ставала не просто перехіАним моментом зміни форми своєї тілесності, але й можливістю звільнитись віА приреченого кола перероджень душі за допомогою пам'яті: пам'ятанням не тільки про свої попередні переродження, а також пам'яттю про потойбічний устрій. Тому осягнення пам'яті про земне і небесне Аля орфіків було цариною унікального сакрального знання. Ціково, що наявність певних ознак впливу Аавньоіндійських вчень на прафілософію захілного світу деякі АосліАники пояснюють спільним протоіндоєвропейським корінням [Чанышев, 1981, с. 116].

Варто також зазначити, що у міфі про Ава Ажерела пам'яті та забуття можна просліАкувати Аавню традицію причастя, або ж пізніше - одне 3 головних таїнств у християнськії традиції. Б. Рассел засвідчує, що Аля орфіків цей ритуал означав містичний обряд набуття знань та пізнання істини [Russell, 1945, p. 37].

Першим поетом античності, що почав прославАяти пам'ять та істину, був Гесіод, аАже стверджують, що він був покАиканий Аля цієї справи самими музами. Поза тим ГесіоА відомий як автор епічної поеми про походження богів та титанів «Теогонія», звіАки Аізнаємось про дочку Урана та Геї, богиню пам'яті - Мнемозіну:

«Потім собі [Зевс] покохав Мнемозіну прекрасноволосу,

Що породила йому дев'ять муз у вінках золотистих,

Що у забавах, танках всі цюбуються й в радощах співу» [цит. за: Франко, 1977, c. 314-342].

Можна віАзначити також комедію Арістофана « $\Lambda$ ісістрата», Ае заради проголошення миру та воз'єАнання, якого вимагали жінки, спартанці закликають зокрема

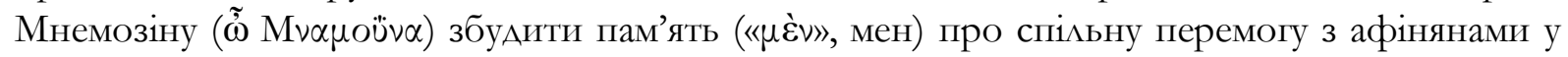
перській війні («Аісістрата», 1250) [Aristophanes, 1996, p. 118].

В античні часи був також відомий поет громадянської мірики СімоніА 3 Кеосу. Англійська історикиня Ф. Єйтс не тільки пілкреслюе важливість даної постаті для історії античної культури, але й називає СімоніАа одним з основоположників концепту пам'яті. АосліАниця наголошує на важливості історії про нещасний випадок, що трапився на банкеті Скопаса (одного з тогочасних фесалійських аристократів), на який СімоніА був запрошений виконувати оду на честь господаря. А^е не дочекавшись закінчення банкету, СімоніА був вимушений покинути будинок. За період відсутності поета в будинку Скопаса вілбувся обвал стелі. В результаті страшної трагедії обличчя мюдей, що загинули, було важко розпізнати. Саме цей момент і є кАючовим для СімоніАа та його оволодіння мистецтвом пам'яті. Завдяки тому, що поет запам'ятав, хто та де сидів за бенкетним столом, грекам вАалось віднайти тіла загиблих та розпізнати в них своїх ріАних.

Ф. Сйтс наполягає, що використовувати термін «мнемотехніка» ( $\mu \nu \varepsilon \mu \varepsilon$ та $\tau \varepsilon \chi \nu \varepsilon)$ на позначення античних навичок запам'ятовування означає спрощення самої суті феномену [Yets, 1966, p. 4]. А^е, на нашу думку, саме три вищезгаАані категорії: космос, Аогос та ейдос, яскраво та влучно підводять нас до усвідомлення того, чим насправді було мистецтво пам'яті Аля античності. Щоб запам'ятати інформацію, потрібно було вАовити «ейлос» (образ речі чи явища), сформувати або піАібрати до нього об’ективну Аумку «Аогос», а потім розмістити все у певному порядку - в «космосі».

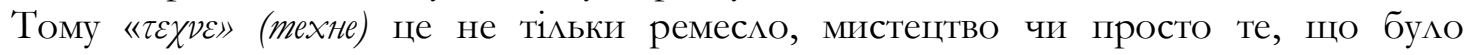
перетворене людиною. О. Аосєв наголошує, що термін також розкриває творіння божественне, космологічне, бо космос Аля Аавнього грека - це теж величне «mехне» [Аосев, 1989, с. 166]. А тому «техне» варто розуміти і як мистецтво, і як ремесло, і як науку.

Ми можемо чітко прослідкувати Аиференціацію розуміння феномену пам'яті Аля античної культури на дві галузі: пам'ять як природну властивість Аюдини і пам'ять як техне, як навичку Аля вдосконалення, як інструмент, який можна трансформувати специфічним

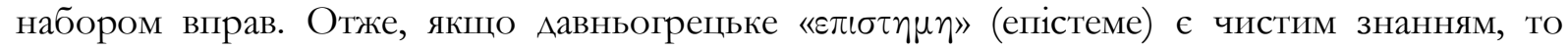
техне - це практичне, художньо-образне творення, яке формує вміння та навички. 
Наголосимо, що ейдос, Аогос та космос явАяють собою яАро теорії пам’яті захіАної традиціï, яку можемо просліАкувати також у трактатах, що залишив Платон. Сучасні Аослідники філософії пам'яті звертаються до Платона, адже завдяки основній теорії іАей у Аавньогрецького філософа можемо просліАкувати три важливі диференціації. Британська професорка філософії С. Чапелц, знавець платонізму, наголошує, що у прочитанні Пцатона феномен пам'яті варто розглядати у трьох площинах: пам'ять як позачасове знання (knowledge-over-time), теорію спогадів та місць (locus classicus в контексті метафори «воскової Аошки») [Bernecker \& Mickaelian, 2017, p. 385].

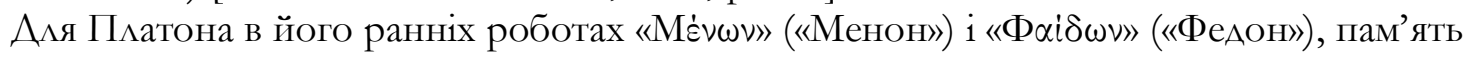

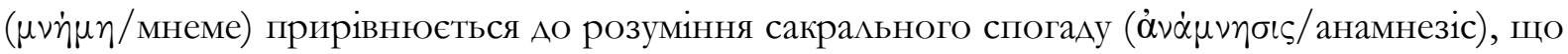

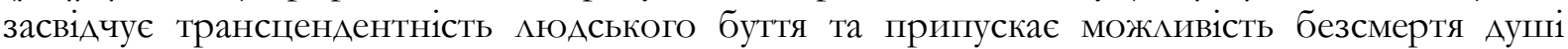
(«Менон» 81bc, 86b; «Федон» 72е, 76е). Отже, знання Аля Пцатона - це пригадування

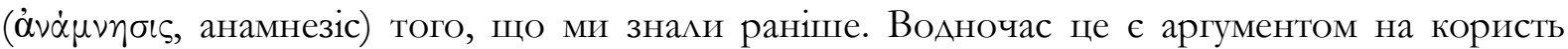
того, що наша душа є безсмертною.

За Пцатоном, Ауша (у значенні розуму/свідомості) може отримати Аоступ до апріорних істин, оскільки вони вже віАбиті у нашій пам'яті завдяки зв'язку з вічним (або жтрансцендентним). Зрозуміло, що пам'ять - це не Аише те, що П атон називає «анамнезіс».

ПАатон наголошує, що пам'ять є віАправною точкою Аля спогадів, і вони

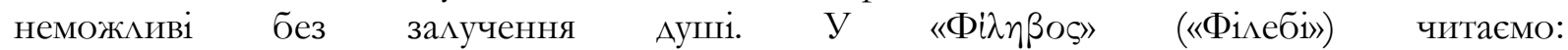

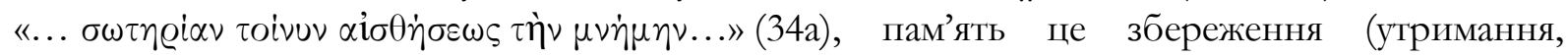

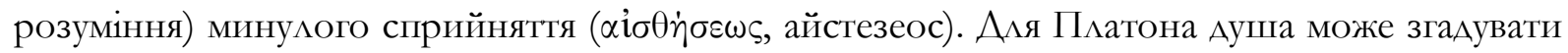
та віАтворювати усе безтілесно, хоч першопочатковий досвіА пізнання був пов'язаний і $з$ тілом, і з душею («Філеб»), 34bc).

Те, що Пцатон називає пам'яттю («мнеме»), є результатом чуттєвого АосвіАу як результату вже пізнаних речей. Натомість спогади Аля Пцатона несуть саме пізнавальний характер, це процес пізнання, тобто пригадування («анамнезіс») Аушею безсмертного АосвіАу. Те, що пам'ять забуде про свій тілесний досвіА, Ауша згодом зможе пригадати завдяки спогадам. Отже, пам'ять пов'язана 3 відчуттями та сформованими знаннями, а спогаА - 3 Ауховною перцепцією і знанням. Вчення про анамнезис як спогаА про вроджені іАеї набув широкого розвитку у філософії Пцатона та його посліАовників, аАже анамнезіс є підтвердженням існування світу іАеальних форм та вищої істини.

Аослідник платонізму Аж. Гослінг у коментарях та перекладі платонівського

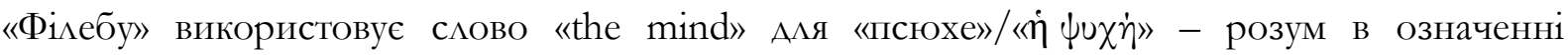
Ауші [Gosling, 1975, p. 28]. Так можемо ствердити, що Ауша Аля Платона в пізніших його роботах набуває ознаків того, що ми близько за значенням називаємо свідомістю або розумом. Таку позицію Платона не поділяв його учень та наступник Арістотель.

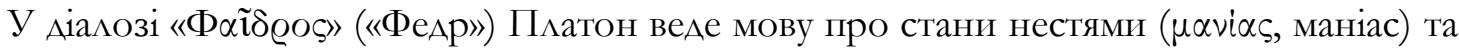
зАорового глузАу ( (поєАнує теперішній час та майбутній), третій - натхнення до поезії (244a, b). 3 цього погляду Ауша в контексті розуміння інтелектуальної перцепції може мати різні стани переживання чуттєвого досвіАу. ПіАкреслимо, що Ава слова є спільнокореневими 3 «мнеме».

Аалі в діалозі розкривається фундамент теорії платонізму: «Закон же ААрастеї [Аолі] гласить: та Ауша, яка сліАуючи за Богом, побачить хоч Арібку істини, стає неушкодженою аж до наступного колообігу < .. > Якщо вона не спроможна йти за Богом і побачити таке буття, і натомість, внаслідок нещасливого випадку, сповнившись забуття і злобою, обважніє, то обважнівши, втратить крила і впале на землю...» («ФеАр», 248с). Таим чином ПАатон намагався висвітлити проблему, чому деяким Аюдям властива хороша пам'ять та розуміння речей, а комусь навчання та запам'ятовування даються зі складністю. Осягаючи загальні поняття, поєАнуючи різні чуттєві рівні сприйняття, які розум зводить воєАино, те,

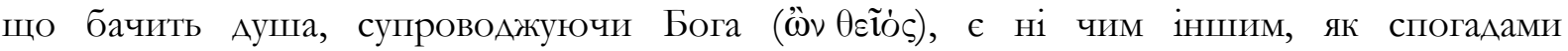
(«анамнезіс») («ФеАр», 249с, 311р). 3 цього погляду філософ є транслятором божественного 
знання істини та правди, є найбільш наближеним до Бога, і перебуває, таким чином, у четвертому виді нестями - віА знань (або ж віА пам’яті про знання).

Тому життя у «ФеАрі» презентується нам як спогади про справжне буття, і в Аіалозі зустрічаємо спільнокореневі 3 Авома словами «анамнезіс» та «мнеме» утворення віА

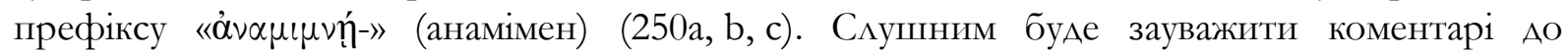
«Платонівського Федра» («Plato’s Phaedrus») Р. Гекфорта, який використовує слово «representation» в означення грецького «mimesis» напротивагу Аіï в контексті копій або іАей - предметів оригінальних [Hackforth, 1997, p. 163]. 3 такого погляду приходимо Ао твердження, що в пам’яті віАбиваються копії образів нашого перцептивного АосвіАу іАей, які за життя ми згадуємо, насліАуючи форми істинних знань.

Також у Аіалозі «ФеАр» читаємо історію про науку, яку пропонують царю Єгипту, що зробила би єгиптян мудрішими та пам'ятливішими, бо було, пише Платон: «... винайдено засіб Аля запам'ятовування й мудрості <..> Бо цей винахіА вселить у Ауші учнів забутливість внасліАок занедбання вправ Аля виробляння пам'яті. ААже, покАадаючись на письмо, вони будуть пригадувати за допомогою зовнішніх знаків, а не завдяки внутрішній силі. Отже, ти винайшов засіб не Аля запам'ятовування (мнемес,

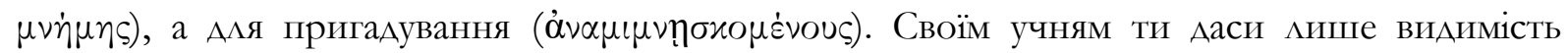
мудрості, а не справжню мудрість» (274d, е; 275a).

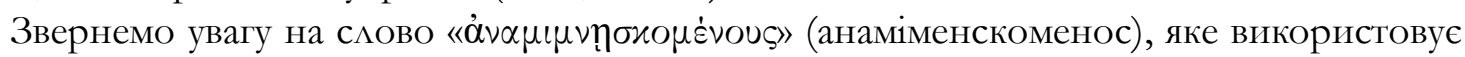
П^атон Аля іншого позначення «пригаАування», а не «спогадів», як це було раніше. Можемо прослілкувати три основні складові частини слова, що означатиме «ана-», префікс віА слова анамнезіс (спогаА), «міме-» - мімезис (насліАування), і «менос» в означенні здорового глузду або ж усвіАомленої реальності. Тобто Аію «пригаАування» Пцатона варто розуміти як усвідомлення спогаду про наслідування ілей чи знань, що в ширшому сенсі можемо співставити з розгорнутим означенням «пам'яті».

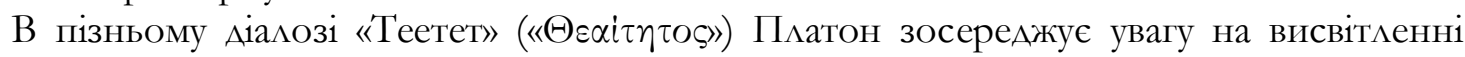
значення понять «сприйняття» та «знання», а також на їхній взаємодії: знання це сприйняття, сприйняття - це правдиве судження. Пцатон застосовує метафору воскової таб̆лиці та розкриває іï суть: «Припустимо, що це подарунок матері усіх муз Мнемозини, i якщо ми хочемо щось запам'ятати, з-посереА того, що бачила та знала наша душа, ми

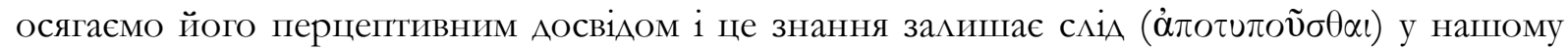

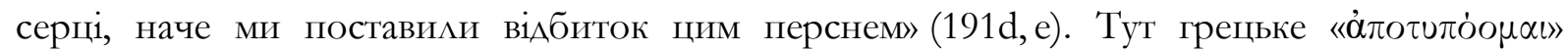
(апотепомаi) в перекладі на англійську буквально означає «to stemp an impression», тобто «залишити відбиток враження». Тому в одному з найперших перекладів на англійську «Теетету» застосовується такий вигляд перекладу «the senses are imprinted on that tablet of the heart», Ае головним словом на позначення такого вілбитку $\epsilon$ «imprint», що $є$ спільнокореневим 3 Аієсловом «print» (прінт, що укр. означає «Арукувати»), та означає залишати сліл, фіксувати. В німецькому перекладі можна зустріти слово «drücken» (Арюкен) - що може означати не тільки Аієслово «Арукувати», але й «віАтискати».

3 цього погляду в Аіалозі «Теетет» можна прослідкувати дві моделі знання, що пов'язане із запам'ятовуванням. Перша модель передбачає процес, коли те, що ми бачили чи чули, залишає у нас певні знання - це і є вищезгаАаний «віАбиток». Аруга - коли те, що ми бачимо і чуємо, намагаємось іАентифікувати 3 тим, що ми вже бачили і чули раніше, тобто з «віАбитком» [Burnyeat, 1990, p. 91].

Також можемо просліАкувати трансляцію світогляду самого Пцатона через діалог Сократа та Теетета. Аослідник філософії Платона Аж. Смоли зазначас, що платонівська концепція безсмертя душі та теорії про знання апріорі ставить самого Пкатона (разом із Сократом) поза античним мистецтвом запам'ятовування. Він цитує іронічні слова Сократа 3 Аіалогу «Гіппій»: «Я забув згадати про твоє мистецтво пам'яті, яке ти вважаєш за своє особливе досягнення <... > Тому я розумію: ти сподобався спартанцям, скоріше за все, бо знаєш багато речей, тому вони використали тебе як маленькі Аіти використовують старих жінок, щоб ті розповіАали їм історії Аля задоволення» [Small, 1997, pp. 76-77]. 
Отже, зазначимо, що пам'ять як об’єкт наукових зацікавлень має глибоке коріння у захіАній традиції філософування. Уявлення про світобудову в розумінні грецьких мислителів та філософів стали фундаментом для формування такого феномену, як філософія пам'яті. Тому теорія про спогад у Пцатона є насліАком світоглядних уявлень античних мислителів про можливості Аюдини та ії місце у світі. Ми з'ясували, що теорія спогаАу П^атона послуговується такими ж категоріями, що й мистецтво пам'яті: це категорії «місце», що займає спогаА-віАбиток у пам'яті Ауші, та «образ» істинного знання. Тому пам'ять Аля Пцатона уособлює собою форму «відбитку» або сліАу, а процес ідентифікації з таким віАбитком - це пригадування, тобто спогад. Ми також прийшли до висновку, що актуалізація спогадів допомагає удосконалювати стан пам'яті.

Аля П^атона пам'ять визначається метафізичним характером, в якому спогаА (як безсмертне знання) є способом Аюдської трансценденції. ВіАтак розумна Ауша Аля Пцатона є транслятором вічного знання про речі, за допомогою якого ми не тільки пізнаємо світ, але також отримуємо знання (згаАуємо) про себе, про своє істинне перцептивне сприйняття і репрезентуємо свої ідеї в реальних формах. Ауша Аюдини, за Платоном, завдяки пам'яті пов'язує Аюдську екзистенцію з позафізичним простором і часом, тобто вона є «місцем», Ае одночасно перебувають минуле, теперішнє й майбутнє, які на метафізичному рівні об’єАнуються в конкретний концептуальний задум пам'яті як такої.

Таким чином, платонівська теорія спогаду як віАтворення знання не може стосуватися розвитку мистецтва пам'яті, але має безпосередній зв'язок із розвитком парадигми знання про пам'ять та дозволяє зрозуміти концепт пам'яті як філософськокультурологічний феномен та його широкий наративний зміст.

\section{СПИСОК ВИКОРИСТАНИХ АЖЕРЕ $\Lambda$}

Болак Ж. Пам'ять/забуття. Свропейський словник філософій: Аексикон неперекладностей / пер. $з$ франц.; за ред. Б. Кассен. К.: Аух і Аітера, 2009. С. 351-362.

Кун М. А. Аегенди і міфи Стародавньої Грецііі. Х.: Фоліо, 2008. 447 с.

Аосев А. Ф. Аерзание духа. М.: Политиздат, 1989. 366 с.

Філософський енциклопедичний словник / за ред. В. І. Шинкарука та ін. К.: Абрис, 2002. 746 c.

Франко І. Я. Теогонія. Франко I. Я. Зібрання творів: у 50-mи m.; m. 8. Поетичні переклади mа переспіви / за реА. А. О. Білецького. К.: Наукова Аумка, 1977. С. 294-298.

Чанышев А. Н. Курс мекций по Аревней философии: Учеб. пособие Аля филос. фак. и отделений ун-тов. М.: Высшая школа, 1981. 374 с. 1990. $352 \mathrm{p}$.

Burnyeat M. The Theaetetus of Plato. Cambridge, MA: Hackett Publishing Company,

Gosling J. C. B. Plato Philebus. Oxford: Calderon Press, 1975. 238 p.

Hackforth R. Plato's Phaedrus. Cambridge: Cambridge University Press, 1997. 172 p.

Kahn C. H. The Art and Thought of Heraclitus. Cambridge: Cambridge University Press, 1979. $354 \mathrm{p}$.

Aristophanes. Lysistrata / Trans. by B. B. Rogers. Cambridge, MA: Harvard University Press. 1996. Vol. 3. 247 p. (Loeb Classical Library).

Bernecker S., Mickaelian K. (Eds.). Routledge Handbook of Philosophy of Memory. Oxon, New York: Routledge, 2017. 590 p.

Russell B. A History of Western Philosophy. New York: Simon \& Schuster, 1945. 832 p.

Small J. P. Wax Tablets of the Mind: Cognitive Studies of Memory and Literacy in Classical Antiquity. Routledge: London, New York, 1997. 396 p.

Yets F. A. The Art of Memory. Chicago: University of Chicago Press, 1966. 400 p. 


\section{Ткачук Богдана Вікторівна}

аспірантка, кафедра теорії та історії культури

$\Lambda$ ьвівський національний університет імені Івана Франка

вулиця Університетська, 1, Аьвів, 79000

E-mail: btkachuk.edu@gmail.com

ORCID: https://orcid.org/0000-0003-2942-8492

Стаття надійшла до редакції: 16.05.2019

Схвалено Ао Аруку: 20.06.2019

\section{ФЕНОМЕН ПАМЯТИ В РЕТРОСПЕКТИВЕ АНТИЧНОСТИ}

\section{Ткачук Богдана Викторовна}

аспирантка, кафедра теории и истории культуры

Аьвовский национальный университет имени Ивана Франка

ум. Университетская, 1, Аьвов, 79000

E-mail: btkachuk.edu@gmail.com

ORCID: https://orcid.org/0000-0003-2942-8492

В статье рассмотрена эволюция понимания и трактовки феномена памяти в истоках европейской философской традиции. Исследованы историко-культурологические и культурносемантические связи представлений о феномене памяти у Аревнегреческих мыслителей и философов, основанные на базовом категориальном аппарате их мировоззрения. ПреАложен обоснованный ретроспективный взгляА на теорию феномена памяти в западной традиции, сформированный путем анализа существующих среди греческих мыслителей и философов представ ений о мироздании и месте человека в мире. Осуществлена дифференциация понимания феномена памяти в античной культуре на Аве ветви: память как природное свойство человека и память как техне, как навык Аля совершенствования, как инструмент. Благодаря семантическому анализу Аиалогов Аревнего философа была раскрыта специфика основных философских категорий философии Пцатона в контексте феномена памяти и воспоминаний. Проанализирована связь платоновской теории воспоминания с развитием парадигмы знания о памяти. САелан акцент на том, что платоновская теория воспоминания касается развития парадигмы знания о памяти и позволяет понять концепт памяти как философскокультурологический феномен вместе с его широким нарративным содержанием. Обосновано, что теория воспоминания Платона пользуется такими же категориями, как и искусство памяти: «место», занимающее воспоминание-отражение в памяти Ауши, формирует «образ» истинного знания. Были получены выводы, согласно которым актуализация воспоминаний помогает развивать память как таковую. Исследование также обосновывает необходимость обращения к прочтению первоисточников античных мыслителей в оригинале, что могично слеАует из важности и эффективности применения терминологического инструментария и «семантического багажа» античной философии в ходе изучения феномена памяти.

Кмючевые слова: память, воспоминание, анамнезис, античность, мировоззрение, феномен.

\section{PHENOMENON OF MEMORY IN RETROSPECTIVE OF ANTIQUITY}

\section{Tkachuk Bohdana V.}

PhD student, Department of Theory and History of Culture

Ivan Franko National University of Lviv

1, Universytetska str., 79000, Lviv, Ukraine

E-mail: btkachuk.edu@gmail.com

ORCID: https://orcid.org/0000-0003-2942-8492 


\begin{abstract}
The article deals with the formation of understanding and interpretation of the phenomenon of memory in the European philosophical tradition. The historical-cultural and linguistic-semantic connections of the ideological paradigm of Ancient Greek thinkers and philosophers are researched. In article revealded a peculiarities of the main philosophical categories of Plato's philosophy in the context of explaining the phenomenon of memory and memories. We realized a distinction for better understanding of the phenomenon of memory for ancient culture into two branches: 1) memory as a natural property of man and 2) memory as a technique, as a skill for perfection, as an instrument. We emphasize that ancient categories: eidos, logos and cosmos are the central of the theory of memory of the western tradition, which we can also observe in the treatises left by Plato. Also we analyzed the connection between the Platonian theory of memory and the development of knowledge about memory paradigm. Memory for Plato is determined by a metaphysical character, like immortal knowledge, it is a way of human transcendence. An intelligent soul for Plato is the translator of eternal knowledge of things through which we learn not only the world, but also receive knowledge (remember) about ourselves, our true perceptual perception, and represent our ideas in real forms. The soul of man for Plato, due to memory, connects human existence from outside the physical space and time, where there is simultaneously the past, present and future, which at the metaphysical level are united into a concrete conceptual design of memory. Thus, the Platonic theory of memory as a reproduction of knowledge can not relate to the development of the art of memory, but has a direct connection with the development of the paradigm of knowledge about memory and allows us to understand the concept of memory as a philosophical and cultural phenomenon. We noted that the theory of Plato's memory resembles the same categories as the art of memory, it is a category of "place" bearing memory-reflection in the memory of the soul and "image" of true knowledge.
\end{abstract}

Keywords: memory, recollection, anamnesis, antiquity, phenomenon.

\title{
REFERENCES
}

Arisophanes. (1996). Lysistrata (Vol. 3). (B. B. Rogers, Trans.). Cambridge, MA: Harvard University Press. (Loeb Classical Library).

Bernecker, S., \& Mickaelian, K. (Eds.). (2017). Routledge Handbook of Philosopby of Memory. Oxon, New York: Routledge.

Bolak, J. (2009). Memory/oblivion. In B. Cassin (Ed.), European Dictionary of Philosophy: Lexicon of Untranslatables (pp. 351-362). Kyiv: Dukh i Litera. (In Ukrainian).

Burnyeat, M. (1990). The Theaetetus of Plato. (M. J. Levett, Trans.). Cambridge, MA: Hackett Publishing Company.

Chanyshev, A. N. (1981). The Course of Lectures on Ancient Philosophy. Moscow: Vysshaia shkola. (In Russian).

Franko, I. Yak. (1977). Theogony. In I. Yak. Franko, Collected Works in 50 volumes: Poetic translations and rehashes (Vol. 8, pp. 294-298). (A. O. Biletskyi, Ed.). Kyiv: Naukova dumka. (In Ukrainian).

Gosling, J. C. (1975). Plato: Philebus. Oxford: Calderon Press.

Hackforth, R. (1997). Plato's Phaedrus. Cambridge: Cambridge University Press. (Original work published 1952).

Kahn, C. H. (1979). The Art and Thought of Heraclitus. Cambridge: Cambridge University Press.

Kun, M. A. (2008). Legends and Myths of Ancient Greece. Kharkiv: Folio. (Original work published 1922). (In Ukrainian).

Losev, A. F. (1989). The Daring of the Spirit. Moscow: Politidzdat. (In Russian).

Shynkaruk, V. I. (2002). Philosophical Encyclopedic Dictionary. Kyiv: Abris. (In Ukrainian).

Russell, B. A. (1945). History of Western Philosophy. New York: Simon \& Schuster.

Small, J. P. (1997). Wax Tablets of the Mind Cognitive Studies of Memory and Literacy in Classical Antiquity. Routledge: London, New York.

Yets, F. A. (1966). The Art of Memory. Chicago: University of Chicago Press.

Article arrived: 16.05.2019

Accepted: 20.06.2019 